\title{
Assessment and Evaluation of Food Waste at AL-Khor Hospital -Hamad Medical Corporation in the State of Qatar
}

\author{
Asma AL-Muhannadi ${ }^{1 *} \quad$ Shitty Vishwas $^{1} \quad$ Sandra Estoya $^{1} \quad$ Jocelyne Hamatosa $^{1}$ \\ Dr. Ghazi Daradkeh Ph. D ${ }^{1 *}$ \\ Department of Dietetics - AL-Khor Hospital (AKH), Hamad Medical Corporation, Qatar
}

\begin{abstract}
Background: Food waste (FW) has been linked with nutrient intake, menu planned, food acceptability, costs, and environmental impacts. Objectives: This project aims to evaluate FW in the units of AL-Khor hospitalHamad Medical Corporation (HMC) in the state of Qatar. Methods: The evaluation of the FW of main meals and nourishments was performed over six months (Jan -June) / 2019, For each client, the type of diet and FW were evaluated during the length of the study (covering 563 meals and 211 snacks). The FW of the dish was calculated by the physical method by weighing before and after distribution. Dietary Intake Monitoring System (DIMS) was used to record plate contents before and after consumption for the 563 patients at 3 main meals and 3 snacks. Results: The average waste rate was calculated as the weighted average of food remaining in the plate in all meals and snacks in relation to the weight of served food. The current study allowed us to estimate that (26.8\%) of the food served in general hospital was wasted. Conclusion: establishing an efficient communication structure involving all actors along the food supply chain contributes to decreasing food waste is crucial.
\end{abstract}

Keywords: food waste; food service facilities; resource efficiency; plate waste (PW); serving losses, $\mathrm{AKH}$, HMC.

DOI: $10.7176 /$ FSQM/109-04

Publication date:June $30^{\text {th }} 2021$

\section{Introduction}

The hospital's food service is a fundamental issue in patient care and being crucial in their recovery [1]. Hospital's food service must provide safe food within the defined standards about nutritional quality, adequacy, palatability, and temperature from the food preparation to the distribution [2]. Meals served in hospital are an important factor in patient treatment and recovery and affected by the length of hospital stay $[3,4]$. The provision of adequate therapeutic diets to the patient should be the responsibility of dietetics and nutrition service of each hospital in collaboration with catering department, and the hospital diet must guarantee the adequate supply of nutrients to the hospitalized patient, allowing it to preserve and/or recover his/her nutritional status through its co-therapeutic role in chronic and acute diseases [5]. Hospital foodservice management focused on discussion food waste (FW) as a vital factor because it causes of many negative effects, including health, economic, social, and environmental issues [6-9]. In hospitals, FW is two to three times greater than in other areas of food services [10]. This study suggested some factors with impact on FW, such as the clinical condition of the patients, the number of portions and the available alternatives, the difficulty in accessing food, the type of menus, the meal production system, and client ethnic [11]. Any removal of food from the food supply chain at human consumption point, spoiled or expired stock management or neglect is defined as food waste. FW can occur anywhere in the world, and food waste may result during any step in the food process including transportation, storage, preparation, cooking, and consumption. Three important categories of food waste including unserved food, untouched food, and uneaten plate waste [12]. Due to the tremendous negative environmental, financial, and social impacts of food waste, global efforts to reduce food waste in all sectors within the food supply chain have recently increased $[13,14]$.

In hospitals food waste is highly important to save money and improve sustainability goals, most food waste in a hospital is that which is thrown away, Unnecessary food waste has been widely acknowledged as problematic, not only because it is linked to financial loss and climate impacts but also because wasting food raises serious social concerns when the nutritional needs of the world's rapidly growing population are not met [15-17]. Approximately 50\% of the total waste generated in hospitals ward environment is food waste. [18,19] and in addition to the nutritional implications of this waste, there are financial and environmental concerns as well.

The reduction of food waste becomes one of the priorities of foodservice management in most of hospitals [20-22]. To minimize the direct negative impact on health care budgets and the related impact on the environment, as well as for the fear of losing credibility of corporate social responsibility status different strategies to reduce food waste have been tried by food service professionals over the years. The most challenging issue in food waste reduction is that related to clinical conditions [23]. 
Many patients are at nutritional risk in hospitals, they eat too little, putting them at risk of complications related to undernutrition. Approximately $30 \%$ of hospitalized patients are at nutritional risk, because of eating problems including, unpredictable changes in appetite and requiring different food items and services [24]. Thus, complications of not meeting nutritional requirements include weakening of the immune system, increased risk of infection, poor wound healing, an increased risk of mortality and increase hospital length of stay [25].

To improve patient nutrition intake strategies have been sought include flexibility of portion size ordering, portion size reduction, options for selective menus, increasing the choice of food items and improved food quality. plate waste is one of the most accurate and applicable method that used to assess food waste in hospitals. Food that is served but not eaten and have been used to provide feedback on food acceptability to help plan menu changes defined as plate waste is [26] and to monitor the adequacy of food intakes [27]. Plate waste in hospitals has always been much higher than other foodservice sectors [28-33]; usually in hospitals, plate waste can be two or three times higher [34]. The volume or percentage of the served food that is discarded refers to Plate waste. Weighing or visual estimation are the two main measurement methods that have been used to assess (PW). Weighing of food waste may include all food waste either the total bulk amount (eg, all meals from one ward), or food remaining on each tray or the weights of each food component on each plate. The latter system is necessary if the data is to be analyzed for its nutrient content either by calculation or analysis. The most accurate method for (PW) assessment is the weighing method, but it requires significant resources and time to complete.

However, it has been used successfully in many studies [35-38]. The proportion of food left in the tray can be measured by visual estimation. Several different scales have been used. A 7-point scale (all, one mouthful eaten, $3 / 4,1 / 2,1 / 4$, one mouthful left, none) is the most extensive method. [39] and the Comstock 6- point scale [40] (all, one bite eaten, $3 / 4,1 / 2,1 / 4$, none). Other scales that have been used are the 5 -point scale (all, $3 / 4,1 / 2,1 / 4$ or less, none or almost none), [41] a 4-point scale (all, $1 / 2,1 / 4$, none) [42]. The median plate waste occurring in hospitals was estimated by $30 \%$, with a wide range from 6 to $65 \%$, as reported in 32 international studies. while the range was estimated by Sonnino, R.; McWilliam, S. 2011 [43,44] from 19\% to 66\%, and 35\% of food served was not consumed by patients but discarded as waste was reported by [45]. A great reduction of food waste in the healthcare sector have been revealed. Other studies from the food service sector that address the economic perspective of food waste emphasized that reducing food waste also offers financial benefits [46]. Engström, R. \& Carlsson-Kanyama, A, 2004 found

on average one fifth of food lost in four Swedish service institutions as waste, with plate waste accounting for about $50 \%$ of waste as the single largest source. In Sweden, additional portions could be served from food discarded in the food service industry in four institutions and calculated economic losses of $€ 657$ (SEK 6030, July 2003) per day [47]. During the four-week measurement period in four hospital wards food waste was worth $£ 139,655$ ( $€ 160,889$, June 2017) as estimated by Barton, A. et al., (2000). The cost of unserved meals on 62 wards approximately $£ 1.5$ million per year has been determined by Brüggemann, H. et al., 2015 [48]. Food waste reduction in an organization can be consider as a continuous improvement process (CIP) as applied in Total Quality Management (TQM) [49].

Generally, an improvement process involves the following steps: Analyze the problem, identify solutions, implement measures, and review results. The current study involves all steps of (TQM). Including: determine and analyze the reasons for food waste and measures are developed accordingly in a participatory approach.

The objectives of the current study are:

(1) To investigate and assess the size of food waste in our institute

(2) To examine the portion size served, consumed, and wasted.

(3) To explore the applicability of the DIMS (Dietary Intake Monitoring System) as an innovative technique for monitoring the amount of plate waste in a hospital setting.

\section{Methods}

\section{Rationale for Research Methodology}

The food waste generation trend in the hospital setting makes it valid to investigate alternative means of achieving a reduction in food waste. Using "whatever works" in a systematic, mindful, and obvious way to answer the research question is the sound basis for the purpose of this study. This way of thinking is inspired by the thinking of the contemporary philosophers such as (Abbas Tashakkori \& Charles Teddlie, 1998) [50], who believe that the researcher should have the liability to study something of interest or that seems to be of great value. They also believe in using different methods if necessary, in a manner that can produce results, have a positive impact on the problem under study, or result in positive change to the society.

This is a prospective observational cohort study conducted in AL-Khor hospital over 6 months for therapeutic diet patients. A total of 563 patients were included. Dietary Intake Monitoring System (DIMS) was used to record plate contents before and after consumption for the 563 patients at 3 main meals and 3 snacks. Prior to the study, a list of patients available on the wards was used for patient selection based on the inclusion criteria of this study. 
The weight of each food item was recorded based on the reference weight obtained from the therapeutic diet main menu. The total weight of all food items on the plate was expected to correspond to the total weight recorded by the DIMS. Estimating the weight of a single portion of each food item on the plate in this manner was helpful to ensure that it was equivalent to the actual total portion size measured. Monitoring of food waste was identified as one of the activities performed by the foodservice professionals to reduce food waste. The findings revealed that meals were ordered based on standard nutritional requirements of patients, which are then translated into predetermined portion sizes in the main menu.

\section{Data collection}

During this study, no personal details were collected from the inpatients evaluated since this study was performed as a quality improvement project. Therefore, it was not submitted to an institutional ethical committee. Besides, to avoid biased results, inpatients on therapeutic diet located on the same floor were only considered and randomly selected in this study.

Additionally, some considerations were considered: - Demographic and social variables like age, sex, socio-economic status, ethics and believes., were out of the scope of this study. It should be noted that the main purpose was neither to evaluate nutritional requirements nor to collect epidemiological information from the selected inpatients. Inpatients did not know beforehand the purpose of this study in order not to interfere with food consumption. Food intake was controlled by the service staff of the hospital in such a way that inpatients remained alone during mealtime. Afterwards, all meal wasting (if any) was collected from the inpatients rooms to avoid biased results when measuring plate waste. Inpatients had the opportunity to choose between the daily prepared meals in the hospital central kitchen. They were allowed choosing from a selective menu that prepared by service staff of the hospital. The study was carried out for six months (Jan -June) / 2019 at AL- Khor hospital - Hamad Medical Corporation in the state of Qatar.

Just before transport to the ward, both chilled and hot meals were placed on the trays according to therapeutic diet order and standardized portions with known the exact weight of each food item under clinical dietetics coordinator supervision. Afterwards, the trays were distributed to inpatients. One hour after, trays were collected (after breakfast, lunch, and dinner time), the remaining food portions on each plate was weighed and recorded using an inventory tool sheet. Food waste then calculated as the weight of remaining of each food item out of weight served of the same food item. Then, Plate waste was calculated as the total weight of remaining food out of the total weight of food served for each meal. Food waste was assessed for the three main meals and three daily snacks. In total 563 meals were served during the study period (275, 203 and 85) meals were served for breakfast, lunch, and dinner meal respectively, as well 211 snacks were served as: 96 morning (AM) snack, 62 afternoon (PM) snack and 53 (HS) snacks. Complete tray waste of discharge from the ward or death was excluded from the study. The weight lost throughout the whole study done by the same trained persons to keep same criterion to classify plate waste was achieved.

\section{Data analysis}

Data analysis was carried out using descriptive statistics such as mean, standard deviation, and confidence intervals $(95 \%)$ were calculated. Besides, average proportions (\%) were calculated for each independent variable (type of menu and snack). For the purpose of this study, foods served were classified into 9 categories as follows: soups, eggs and egg-based dishes' (i.e., boiled eggs, omelet etc.), meat and meat-based dishes, bread, pasta and rice, seasonal fruit, yogurt, salads (i.e., mixed salads or lettuce-based salads), cooked vegetables (i.e., cauliflower, boiled vegetables). Additionally, three timetables were considered (breakfast time, lunch time and dinner time) to evaluate significant differences among them.

\section{Results}

During the study period, 275 (49\%), 203 (36\%) and 85 (15\%) main meals were served for breakfast, lunch, and dinner respectively, as well 211 snacks were served as: 96 (46\%) morning (AM) snack, 62 (29\%) afternoon (PM) snacks and 53 (25\%) (HS) snacks figure $1 \mathrm{a} \& \mathrm{~b}$. 
Figure 1 a: Main Meals Distribution

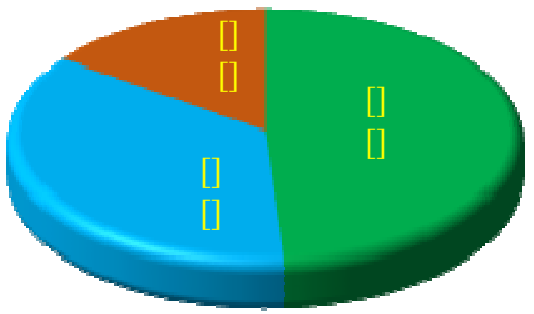

Figure 1 b: Snacks Distribution

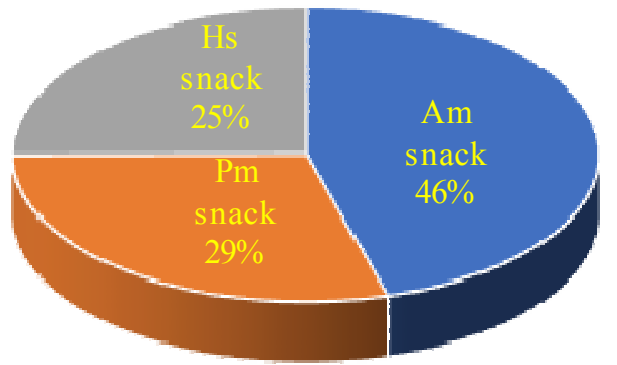

The highest Mean plate waste was found in dinner meal followed by lunch and breakfast meals, while the lowest waste was found in AM snack followed by PM and HS snacks. The overall plate waste among main meals and snacks was $26.8 \%$ figure 2 .

Figure 2. Overall, mean plate waste per meals and snacks (\%)

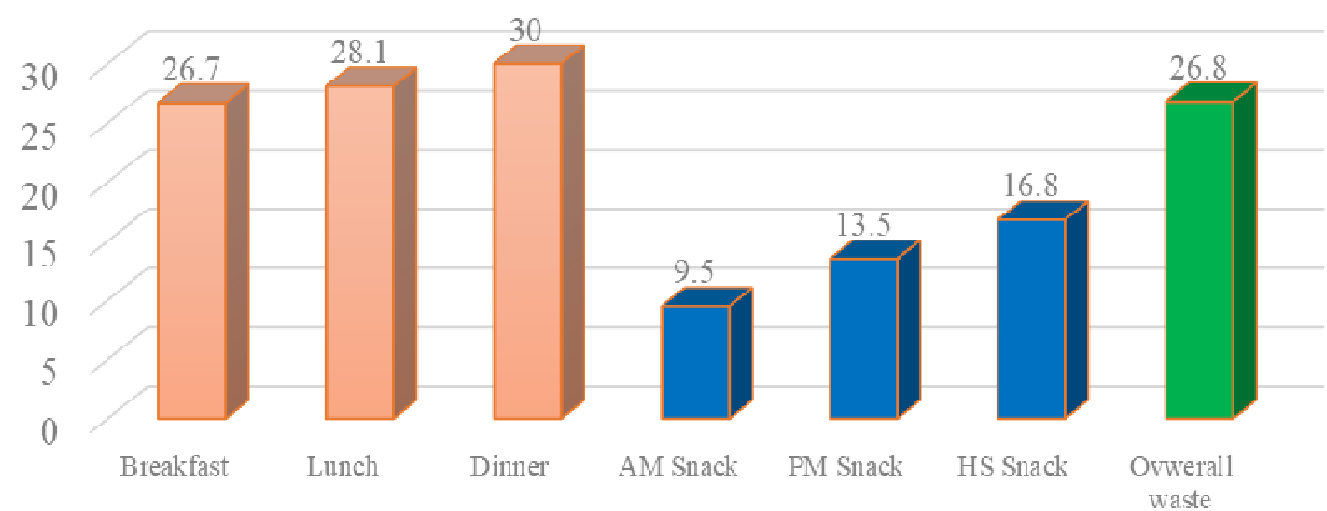

563 main meals and 211 snacks were served during the study period. On breakfast $141.7 \mathrm{~kg}$ was served with $26.7 \%$ plate waste, while $171.7 \mathrm{~kg}$ of food were served on lunch and $26.9 \mathrm{~kg}$ on dinner with $28.1 \%$ \& $32.7 \%$ plate waste for lunch and dinner, respectively. Nourishment weight served were $13.8 \mathrm{~kg}, 5.7 \mathrm{~kg}$ and $6.5 \mathrm{~kg}$ on AM, PM \& HS snacks respectively, with plate waste of 9.5,13.5, \&16.8 \% on AM, PM, and HS snacks, respectively. The overall amount of food waste was calculated as the weighted average of food remaining in the plate in all meals and snacks in relation to the weight of served food. The current study allowed us to estimate that $(98.1 \mathrm{~kg} \approx 26.8 \%)$ of the food served in this general hospital was wasted table 1 .

Table 1. Shows the weight of meal portion served, consumed, wasted and waste percent of different meals and snacks.

\begin{tabular}{|c|c|c|c|c|}
\hline Meal / Snack & $\begin{array}{c}\text { Portion Served } \\
(\mathrm{Kg})\end{array}$ & $\begin{array}{c}\text { Portion Consumed } \\
(\mathrm{Kg})\end{array}$ & $\begin{array}{c}\text { Portion Wasted } \\
(\mathrm{Kg})\end{array}$ & \% Plate Waste \\
\hline Breakfast & 141.7 & 104.0 & 37.7 & 26.7 \\
\hline Lunch & 171.7 & 123.4 & 48.3 & 28.1 \\
\hline Dinner & $26.9^{*}$ & 18.1 & 8.8 & 32.7 \\
\hline AM Snack & 13.8 & 12.5 & 1.3 & 9.5 \\
\hline PM Snack & 5.7 & 4.9 & 0.8 & 13.5 \\
\hline HS Snack & 6.5 & 5.4 & 1.1 & 26.8 \\
\hline Total & 366.3 & 268.9 & 98.1 & 26.8 \\
\hline
\end{tabular}

*Data collected over 4 weeks only

Each serving corresponding to an individual meal consisted of 6 different dishes (starch, protein source, milk and milk products, vegetables, legumes and honey/jam) for breakfast and (starch, protein source, dairy products, cooked vegetables, salad and soup) for lunch and dinner meals. On breakfast meal protein source was the highest plate waste $63 \%$ followed by starch $55 \%$, while milk was the lowest waste on breakfast. On the other hand, salad, soup, and cooked vegetables were the highest waste on lunch meal $(38,37 \& 35 \%)$ respectively while dairy products were the lowest waste $15 \%$. Cooked vegetables, salad in dinner meal were the highest waste 
$42.43 \%$ respectively, while dairy products were the lowest $11 \%$ figure 3 ( $a, b, c)$

Figure $3-\mathrm{a} \%$ of waste per food item on each meal

Figure 3 - a (Breakfast)

Figure 3 - b (Lunch)
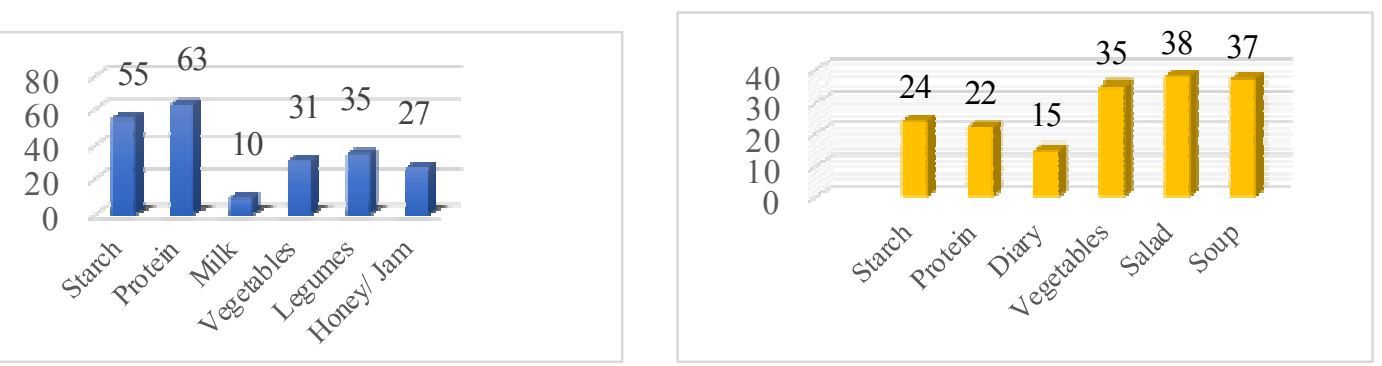

Figure 3 - c (Dinner)

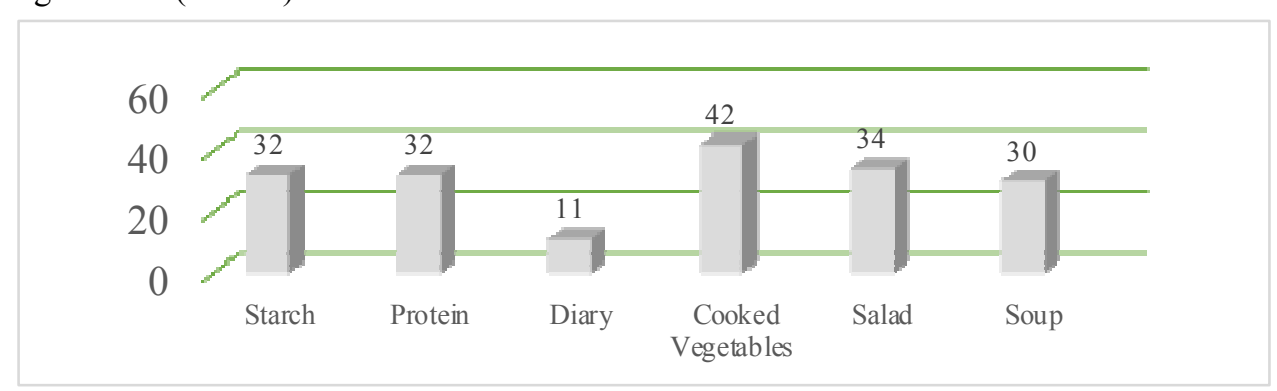

\section{Discussion}

This study of hospital food service organizations in Qatar confirmed that most have already taken the initiative to implement measures to quantify and reduce food waste. Currently, serving waste and plate waste from hospital meals are the most common elements quantified, and quantification takes place during the study period. Food waste data related to the number of plates was reported by using data collection sheet and the compiled results are expressed in mass of food waste per portion served. Based on the present study, it appears that AL-Khor hospitals can match the food waste quantification efforts in the hospitals.

The high level of plate waste reported by the current study is consistent with findings in other studies in different hospitals [51]. This is also in line with the records from other hospitals that provided their data, where the waste consisted of $42 \%$ plate waste, $36 \%$ serving waste, and $22 \%$ kitchen waste.

The present study carried out in general hospital in the state of Qatar, which typically serve breakfast, lunch, and dinner meals, at no cost to patients. The meals served to patients can vary depending on whether their illness requires a therapeutic diet. A typical meal comprises a cooked dish based on poultry, fish, meat, or a vegetarian alternative, often served together with rice, pasta, or potatoes. Meals may also include a salad and/or cooked vegetables, water or other beverages, and bread. There are several ways in which the food is usually served, but the most common is prepared trays in hospital wards. There are multiple reasons why plate waste is especially common in hospitals, including clinical issues, such as poor appetite and medication- altered taste, food and menu issues, such as no choice, service issues, such as complex ordering systems, and eating environment issues, such as the meal being interrupted by ward rounds and tests, the ward environment, and inappropriate mealtimes [52].

An à la carte menu is served on demand to patients AS room service model is becoming more common in hospitals internationally. less plate waste, increased patient intake, improved patient satisfaction, and decreased costs has been reported by room service system to result in compared with the conventional food service model [53], but few hospitals use this system. To our knowledge, this is the first study about inpatient food waste in the state of Qatar. According to this methodology, 26.8\% of the food served was wasted at AL-Khor hospital, with the side plate being the most often discarded dish. This rate is close to the highest rates identified by other studies, both recent and older, most of which reported rates ranging between $25 \%$ and $40 \%$ [54-63]. The overall prevalence of food waste $(26.8 \%)$ founded by the current study was inconsistence with Italian hospitals in several studies in the Piedmont region [64] reported that $31.2 \%$ of the food served was wasted. The overall waste rate to well over $50 \%$, when our results account for the food wasted along the supply chain. Food acceptability was measured by several visual inspections of meals wastage belonging to different menus served throughout this study. To meet a range of key performance indicators within the health care setting, hospital foodservice models becomes one of the comprehensive measurements. Some research has shown the benefits of room service in decreasing food costs and waste, $[65,66]$, while other research has evaluated the improvement in patient satisfaction [67-69]. However, there is a lack of literature on the impact on patient nutritional intake. This 
is the first study to comprehensively measure the amount of food waste using plate waste model in the state of Qatar.

\section{Conclusion}

Food waste reduction is considered an important issue that hospitals can use to improve sustainability, by lowering the environmental impact from food production to final landfilling of uneaten food. The very high levels recorded in many of the studies suggest that more needs to be done to support adequate patient food intakes and improve operational efficiency. Some attempts have been made to develop targets for acceptable plate waste levels, but ultimately it is important for each institution to monitor their own performance and improve the nutritional intakes of their vulnerable patients. Each institution should pay attention to the sources of the food and keep track of the food waste that has been increased in some hospitals. Food waste should be monitored and controlled for each meal that has been served to the patient. food waste may reduce by Monitoring and improving hospital facilities Also, by knowing the reasons for food waste and applying all possibilities to change whether the service system, menus, time serving, patients' preferences, staff training, communications, quality of food and variation can lead to a reduction in food waste.

\section{References}

[1]. Jonkers, C.F.; Prins, F.; Van Kempen, A.; Tepaske, R.; Sauerwein, H.P. Towards implementation of optimum nutrition and better clinical nutrition support. Clin. Nutr. 2001, 20, 361-366. [CrossRef] [PubMed]

[2]. Davis, A.M.; Bristow, A. Managing Nutrition in Hospital: A Recipe for Quality; Nuffield Trust: London, UK, 1999

[3]. Greathouse, K.R.; Gregoire, M.B. Variables related to selection of conventional, cook-chill, and cook-freeze systems. J. Am. Diet. Assoc. 1988, 88, 476-478. [PubMed]

[4]. Hickson, M.; Fearnley, L.; Thomas, J.; Evans, S. Does a new steam meal catering system meet patient requirements in hospital? J. Hum. Nutr. Diet. 2007, 20, 476-485. [CrossRef]

[5]. Allard, J.P.; Keller, H.; Teterina, A.; Jeejeebhoy, K.N.; Laporte, M.; Duerksen, D.R.; Gramlich, L.; Payette, H.; Bernier, P.; Davidson, B.; et al. Factors associated with nutritional decline in hospitalised medical and surgical patients admitted for $7 \mathrm{~d}$ or more: A prospective cohort study. Br. J. Nutr. 2015, 114, 1612-1622. [CrossRef] [PubMed]

[6]. Almdal, T.; Viggers, L.; Beck, A.M.; Jensen, K. Food production and wastage in relation to nutritional intake in a general district hospital-wastage is not reduced by training the staff. Clin. Nutr. 2003, 22, 47-51. [CrossRef]

[7]. Barton, A.D.; Beigg, C.L.; Macdonald, I.A.; Allison, S.P. High food wastage and low nutritional intakes in hospital patients. Clin. Nutr. 2000, 19, 445-449. [CrossRef]

[8]. Edwards, J.S.; Nash, A.H. The nutritional implications of food wastage in hospital food service management. Nutr. Food Sci. 1999, 99, 89-98. [CrossRef]

[9]. Scherhaufer, S.; Moates, G.; Hartikainen, H.; Waldron, K.; Obersteiner, G. Environmental impacts of food waste in Europe. Waste Manag. 2018, 77, 98-113. [CrossRef]

[10]. Williams, P.; Walton, K. Plate waste in hospitals and strategies for change. Eur. e-J. Clin. Nutr. Metab. 2011, 6, e235-e241. [CrossRef]

[11]. Schiavone, S.; Pelullo, C.P.; Attena, F. Patient Evaluation of Food Waste in Three Hospitals in Southern Italy. Int. J. Environ. Res. Public Health 2019, 16, 4330. [CrossRef]

[12].Jonkers, C.F.; Prins, F.; Van Kempen, A.; Tepaske, R.; Sauerwein, H.P. Towards implementation of optimum nutrition and better clinical nutrition support. Clin. Nutr. 2001, 20, 361-366. [CrossRef] [PubMed]

[13]. European Commission. (2010). Preparatory study on food waste across EU 27 (final report). Paris, France: European Commission in Association with AEA Energy, Umwelt Bundesamt and Environment and BIO Intelligence Service

[14]. Williams, P., \& Walton, K. (2011). Plate waste in hospitals and strategies for change. E-SPEN, the European e-Journal of Clinical Nutrition and Metabolism, 6(6), e235-e241.

[15]. Global Initiative on Food Loss and Waste Reduction. January 2015. Retrieved 2016-06-09.

[16]. Bellemare, Marc F.; Çakir, Metin; Peterson, Hikaru Hanawa; Novak, Lindsey; Rudi, Jeta (2017). "On the Measurement of Food Waste". American Journal of Agricultural Economics.99 (5): 11481158. doi:10.1093/ajae/aax034

[17]. (Stuart, 2009). Stuart, T. (2009). Waste: uncovering the global food scandal. WW Norton \& Company.

[18]. Alam M, Sujuaddin M, Iqbal G, Huda S. Healthcare waste characterization in Chittagong medical college hospital, Bangladesh. Waste Manage Res 2008;26:291e6.

[19]. Mattoso V, Schalch V. Hospital waste management in Brazil: a case study. Waste Manage Res 2001; 19:567e72.

[20]. Byers B, Shankin C. Get your food service waste (and costs) out of the garbage. Health Facil Manag 1997; 
10:56e61.

[21]. NHSE Hospitality. Managing food waste in the NHS. Leeds, UK: Department of Health; 2005.

[22]. Bates M, Phillips P. Waste minimisation in the food and drink industry. Nutr Food Sci 1998; 98:330e4.

[23]. Williams, P., \& Walton, K. (2011). Plate waste in hospitals and strategies for change. E-SPEN, the European e-Journal of Clinical Nutrition and Metabolism, 6(6), e235-e241.

[24]. (Dupertuis et al., 2003; J. Edwards \& Hartwell, 2003; J. Edwards \& Hartwell, 2006; McWhirter \& Pennington, 1994)

[25]. McWhirter, J. P., \& Pennington, C. R. (1994). Incidence and recognition of malnutrition in hospital. BMJ (Clinical Research Ed.), 308(6934), 945-948.

[26]. Connors P, Rozell S. Using a visual plate waste study to monitor menu performance. J Am Diet Assoc 2004; 104:94e6.

[27]. Huls A. Decreased plate waste: a sign of meeting resident needs. J Am Diet Assoc 1997; 97:882.

[28]. Engstrom R, Carslsson-Kanyama A. Food losses in food service institutions. Examples from Sweden. Food Policy 2004; 29:203e13.

[29]. Banks G, Collison R. Food waste in catering. Proc Inst Food Sci Technol 1981; 14:181e9.

[30]. Collison R, Colwill J. The analysis of food waste results and related attributes of restaurants and public houses. J Foodserv Syst 1986; 4:17e30.

[31]. Youngs A, Nobis G, Town P. Food waste from hotels and restaurants in the UK. Waste Manage Res 1983; $1: 295 \mathrm{e} 308$.

[32]. Edholm O, Adam J, Healy M, Wolff H, Goldsmith R, Best T. Food intake and energy expenditure of army recruits. Br J Nutr 1970; 24:1091e107.

[33]. Kelley S, Jennings G, Funk K, Gaskins C, Welch G. Edible plate waste assessment in a university dining hall. J Am Diet Assoc 1983; 83:436e40.

[34]. Edwards J, Hartwell H. Is there such a thing as 'reasonable' or acceptable levels of food wastage in hospital food services? Food Serv Technol 2003; 3:23e7.

[35]. Frakes E, Arjmandi B, Halling J. Plate waste in a hospital cook-freeze production system. J Am Diet Assoc $1986 ; 86: 941 \mathrm{e} 2$.

[36]. Edwards J, Nash A. The nutritional implications of food wastage in hospital food service management. Nutr Food Sci 1999; 2:89e98.

[37]. Wilson A, Evans S, Frost G. A comparison of the amount of food served and consumed according to meal service system. J Hum Nutr Diet 2000; 13:271e5.

[38]. Dilly G, Shanklin C. Waste/residues generated in food service operations: military healthcare food service operations generate more food and packaging wastes than other non-commercial and commercial facilities. Food Serv Technol 2003; 3:29e35.

[39]. Sherwin A, Nowson C, McPhee J, Alexander J, Wark J, Flicker L. Nutrient intake at meals in residential care facilities for the aged: validated visual estimation of plate waste. Aust J Nutr Diet 1998; 55:188e93.

[40]. Comstock E, St Pierre R, Mackiernan Y. Measuring individual plate waste in school lunches. J Am Diet Assoc 1980,79.

[41]. Graves K, Shannon B. Using visual plate waste measurement to assess school lunch food behavior. J Am Diet Assoc 1983; 82:163e5.

[42]. Hiesmayr M, Schindler K, Pernicka E, Schuh C, Schoeniger-Hekeler A, Bauer P, et al. Decreased food intake is a risk factor for mortality in hospitalised patients: The Nutrition Day survey 2006. Clin Nutr 2009;28: 484e91.and a 3-point scale (all, 50\%, e (all, 50\%, <50\%). (43).

[43]. Kandiah J, Stinnett L, Lutton D. Visual plate waste in hospitalized patients: length of stay and diet order. J Am Diet Assoc 2006; 106:1663e6.

[44]. Sonnino, R.; McWilliam, S. Food waste, catering practices and public procurement: A case study of hospital food systems in Wales. Food Policy 2011, 36, 823-829.,

[45]. Dias-Ferreira et al Dias- Ferreira, C.; Santos, T.; Oliveira, V.Hospitalfoodwasteandenvironmentalandeconomicindicators-A Portuguese-case study. Waste Manag. 2015, 46, 146-154. [CrossRef] [PubMed]

[46]. Engström, R.; Carlsson-Kanyama, A. Food losses in food service institutions: Examples from Sweden. Food Policy 2004, 29, 203-213. [CrossRef]

[47]. Barton, A.; Beigg, C.; MacDonald, I.; Allison, S. High food wastage and low nutritional intakes in hospital patients. Clin. Nutr. 2000, 19, 445-449. [CrossRef] [PubMed]

[48]. Wales Audit Office: Hospital Catering and Patient Nutrition. Available online: http://www.audit. wales/system/files/publications/Hospital_Catering_and_Patient_Nutrition_English_2011.pdf (accessed on 3 July 2017).

[49]. Brüggemann, H.; Bremer, P. Grundlagen Qualitätsmanagement: Von den Werkzeugen Über Methoden zum TQM, 2nd ed.; Springer: Wiesbaden, Germany, 2015. (In German) . 
[50]. Abbas Tashakkori, \& Charles Teddlie. (1998). Mixed methodology: Combining qualitative and quantitative approaches Sage.

[51] Williams, P.; Walton, K. Plate waste in hospitals and strategies for change. e-SPEN Eur. e-J. Clin. Nutr. Metab. 2011, 6, e235-e241. [CrossRef]

[52]. Williams, P.; Walton, K. Plate waste in hospitals and strategies for change. e-SPEN Eur. e-J. Clin. Nutr. Metab. 2011, 6, e235-e241. [CrossRef]

[53]. McCray, S.; Maunder, K.; Krikowa, R.; MacKenzie-Shalders, K. Room Service Improves Nutritional Intake and Increases Patient Satisfaction While Decreasing Food Waste and Cost. J. Acad. Nutr. Diet. 2018, 118, 284-293. [CrossRef]

[54]. McCray S., Maunder K., Norris R., Moir J., MacKenzie-Shalders K. Bedside Menu Ordering System increases energy and protein intake while decreasing plate waste and food costs in hospital patients. Clin. Nutr. 2018; 26:66-71. doi: 10.1016/j.clnesp.2018.04.012. [PubMed] [CrossRef] [Google Scholar]

[55]. Simzari K., Vahabzadeh D., Nouri Saeidlou S., Khoshbin S., Bektas Y. Ingesta y desperdicio de alimentos y su asociación con la desnutrición hospitalaria. Nutr. Hosp. 2017; 34:1376-1381. [PubMed] [Google Scholar]

[56]. Dias-Ferreira C., Santos T., Oliveira V. Hospital food waste and environmental and economic indicatorsA Portuguese case study. Waste Manag. 2015; 46:146-154. doi: 10.1016/j.wasman.2015.09.025. [PubMed] [CrossRef] [Google Scholar]

[57]. Valero Díaz A., Caracuel García A. Evaluation of factors affecting plate waste of inpatients in different healthcare settings. Nutr. Hosp. 2013; 28:419-427. [PubMed] [Google Scholar]

[58]. van Bokhorst-de Schueren M.A.E., Roosemalen M.M., Weijs P.J.M., Langius J.A.E. High waste contributes to low food intake in hospitalized patients. Nutr. Clin. Pract. 2012; 27:274-280. doi: 10.1177/0884533611433602. [PubMed] [CrossRef] [Google Scholar]

[59]. Hickson M., Connolly A., Whelan K. Impact of protected mealtimes on ward mealtime environment, patient experience and nutrient intake in hospitalised patients. J. Hum. Nutr. Diet. 2011; 24:370-374. doi: 10.1111/j.1365-277X.2011.01167.x. [PubMed] [CrossRef] [Google Scholar]

[60]. Mudge A.M., Ross L.J., Young A.M., Isenring E.A., Banks M.D. Helping understand nutritional gaps in the elderly (HUNGER): A prospective study of patient factors associated with inadequate nutritional intake in older medical inpatients. Clin. Nutr. 2011; 30:320-325. doi: 10.1016/j.clnu.2010.12.007. [PubMed] [CrossRef] [Google Scholar]

[61]. Almdal T. Food production and wastage in relation to nutritional intake in a general district hospitalWastage is not reduced by training the staff. Clin. Nutr. 2003; 22:47-51. doi: 10.1054/clnu.2002.0590. [PubMed] [CrossRef] [Google Scholar]

[62]. Barton A.D., Beigg C.L., Macdonald I.A., Allison S.P. High food wastage and low nutritional intakes in hospital patients. Clin. Nutr. 2000; 19:445-449. doi: 10.1054/clnu.2000.0150. [PubMed] [CrossRef] [Google Scholar]

[63]. Wilson A., Evans S., Frost G. A comparison of the amount of food served and consumed according to meal service system. J. Hum. Nutr. Diet. 2000; 13:271-275. doi: 10.1046/j.1365277x.2000.00235.x. [CrossRef] [Google Scholar]

[64]. Regione Piemonte Progetto Di Valutazione Degli Scarti Dei Pasti. [(accessed on 14 January 2019)]; Available online: https://www.regione.piemonte.it/sanita/cms2/documentazione/category/152-retedietistica-e-nutrizione-clinica?start $=20$.

[65]. W. Marcason What is the current direction for hospital room service? J Acad Nutr Diet, 112 (3) (2012), p. 456 ArticleDownload PDFView Record in ScopusGoogle Scholar

[66]. A.S. Doorduijn, Y. van Gameren, E. Vasse, N.M. de Roos At Your Request (R) room service dining improves patient satisfaction, maintains nutritional status, and offers opportunities to improve intake Clin Nutr, 35 (5) (2015), pp. 1174-1180 Google Scholar

[67]. K. Wadden, B. Wolf, A. Mayhew Traditional versus room service menu styles for pediatric patients Can J Diet Pract Res, 67 (2) (2006), pp. 92-94CrossRefView Record in ScopusGoogle Scholar

[68]. A. Houlston, E. Buttery, B. Powell Cook to order: Meeting the nutritional needs of children with cancer in hospital Pediatr Nurs, 21 (4) (2009), pp. 25-27 View Record in ScopusGoogle Scholar

[69]. V. McLymont, S. Cox, F. Stell Improving patient meal satisfaction with room service meal delivery J Nurs Care Qual, 18 (1) (2003), pp. 27-37 CrossRefView Record in ScopusGoogle Scholar 